\title{
PROSES PENGUATAN KARAKTER DISIPLIN BELAJAR TERHADAP SISWA MELALUI KEGIATAN PEMBIASAAN PADA PEMBELAJARAN HYBRID LEARNING
}

\author{
Reksa Adya Pribadi ${ }^{1}$, Nurhalisza², Nurhaliza Febrianti ${ }^{3}$, \\ Universitas Sultan Ageng Tirtayasa \\ ${ }^{1}$ reksapribadi@untirta.ac.id, ${ }^{2} 2227190087 @ u n t i r t a . a c . i d$, \\ 32227190096@untirta.ac.id
}

\begin{abstract}
Since the onset of COVID-19 in Indonesia, schools have implemented online learning. With online learning causes a decrease in the character of student discipline. such as students late in submitting assignments. Then at the end of 2020 in December there were already several schools that implemented face-toface learning in part or what was called hybrid learning. Hybrid learning is learning divided into two learning sessions in which some students do online learning at home and some students study at school face-to-face with teachers and friends. The disciplined character of today's society is starting to decline. Especially in elementary school students. Which at the elementary school level is the foundation for students to have good character, especially the character of discipline. Strengthening the character of discipline is not only from the family environment but can be done in the school environment. In the school environment, it can be started with learning discipline. Strengthening the character of learning discipline is an effort made to improve and regenerate the character of learning discipline in students through habituation activities. The method used is a qualitative approach. The results of the research carried out are seen from the habituation activities carried out in schools such as literacy and also the Saturday clean program with this habituation program can support the process of strengthening the character of learning discipline for students. So that there is an increase in the discipline character of students through these habituation activities that the process of strengthening the discipline character at SDN Anyar 2 which is carried out during this hybrid learning is quite good.
\end{abstract}

Keywords : discipline character, habituation activities, hybrid learning

\begin{abstract}
ABSTRAK
Semenjak adanya covid-19 di Indonesia sekolah menerapkan pembelajaran daring. Dengan pembelajaran daring menyebabkan menurunnya karakter disiplin siswa. seperti siswa telat mengumpulkan tugas. Kemudian pada akhir tahun 2020 bulan desember sudah ada bebrapa sekolah yang menerapkan pembelajran tatap muka sebagian atau yang disebuat dengan hybrid learning. Pembelajaran hybrid
\end{abstract}


merupakan pembelajaran terbagi atas dua sesi pembelajaran yang mana sebagian siswa melakukan pembelajaran dirumah melalui daring dan sebagian siswa belajar di sekolah tatap muka dengan guru dan teman teman. Karakter disiplin yang dimiliki masyarakat sat ini mulai menurun. Terutama pada siswa Sekolah Dasar. Yang mana pada tingkat sekolah dasar ini menjadi pondasisi untuk siswa memiliki karakter yang baik terutama karakter disiplin. Penguatan karakter disiplin bukan hanya dari lingkungan keluarga tetapi bisa dilakuakn di lingkungan sekolah. Di lingkungan sekolah bisa dimulai dengan disiplin belajar. Penguatan karakter disiplin belajar merupakan suatu usaha yang dilakukan untuk meningkatkan dan menumbuhkan kembali karakter disiplin belajar pada siswa melalui kegiatan pembiasaan.penelitian ini bertujuan untuk mengetahui seperti apa penguatan karekter disiplin belajar siswa melalui kegiatan pembiasaan pada pembelajaran Hybrid. Metode yang digunakan adalah pendekatan kualitatif. Hasil penelitan yang dilakukan dilihat dari Kegiatan pembiasaan yang dilakukan disekolah seperti leterasi dan juga program sabtu bersih dengan program pembiasaan ini dapat mendukung proses penguatan karakter disiplin belajar terhadap siswa. Sehingga terjadi peningkatan karakter disiplin siswa melalui kegiatan pembiasaan tersebut bahwa proses penguatan karakter disiplin di SDN Anyar 2 yang dilaksanakan saat pembelajaran hybrid ini sudah cukup baik.

Kata kunci : karakter disiplin, kegiatan pembiasaan, pembelajaran hybrid

\section{A. Pendahuluan}

Bermula dari satu kota yaitu Wuhan yang berada di Provinsi Hubei, China, Virus yang bernama virus corona(covid-19). Hal ini menyebabkan sejumlah orang dinyatakan terinfeksi virus corona dan menyebabkan banyak kasus kematian. Tepatnya pada bulan Januari 2020, beberapa negara seperti Thailand, Singapura, Vietnam, Malaysia dan Filipina mulai melaporkan kasus pertamanya. Sdangkan di Indonesia sendiri kasusu petam muncul pada bulan Maret 2020, dimana berita ini diumumkan langsung oleh presiden Joko Widodo bahwa ada dua warga Indonesia yang terjangkit virus corona.

Menurut Satgas penanganan Covid-19 jumlah peningkatan kasus di Indonesia bisa mencapai 3.000 
kasuus perhari. Dengan demikian, jumlah angka penyebaran virus corona (Covid-19) bisa saja semakin bertambah. Sehingga membuat beberapa wilayah harus menerapkan Pembatasan Sosial Berskala Besar (PSBB) dan memebuat beberapa sektor terkena imbasnya. Saat ini dampak dari bebrapa sector tersebut mulai dirasakan oleh masyarakat. Tidak hanya pada sektor kesehatan saja, adanya virus covid-19 ini berdampak juga pada sektor ekonomi, sektor pendidikan hingga kegiatan beribadah. Dapat ditarik kesimpulan bahwa tingkat penyebaran virus di Indonesia masih terbilang tinggi.

Hal ini dapat dibuktikan dengan melihat banyaknya masyarakat Indonesia yang belum menerapkan protokol Kesehatan atau peraturan yang sudah dibuat, seperti selalu menggunakan masker, menjaga jarak, dan mencuci tangan menggunakan sabun ataupun menggunakan hand sanitizer. Terdapat bebrapa faktor salah satunya adalah kurangnya sikap disiplin masyarakat Indonesia disebabkan oleh kurangnya penerapan disiplin sejak dini.
Karakter disiplin akan terwujud melalui pembinaan atau pembentukan karakter disiplin sejak dini. pembentukan disiplin dapat dilakukan dari lingkup terkecil, mulai dari keluarga dan lingkungan sekolah. Karakter disiplin bisa dicerminkan dengan mematuhi peraturan dan tata tertib. Karakter disiplin juga muncul akibat sebuah kebiasaan dan pelatihan dari aturan yang ada dalam menjalani kehidupan. Menurut yang dikutif oleh Annisa Fadhillah (2019:2) disiplin merupakan suatu yang berkenaan pada pengendalian diri seseorang dalam bentuk-bentuk aturan. Sikap disiplin ditunjukan kepada orangorang yang selalu hadir tepat waktu, taat terhadap aturan, berperilaku sesuai dengan norma-norma yang berlaku.

Pembentukan karakter disiplin selain dilingkungan keluarga, pembentukan karekter disiplin juga bisa dilakukan saat siswa dilingkungan sekolah. Pendidikan di Indonesia memusatkan pendidikan kepada pendidikan karakter pendidikan karakter tersebut penting dalam pendidikan di Indonesia. Menurut Lickona dalam (Muchlish, 2011: 44) yang dikutip kembali oleh 
Utami, Septi Wahyu (2019:64) pendidikan karekter adalah sebagai upaya yang sudah disusun dengan sengaja dengan tujuan memperbaiki karekter siswa. Dalam memperoleh pendidikan karakter ini dapat diperoleh dari lingkungan keluarga dan lingkungan sekolah.

Salah satu cara untuk membentuk karakter disiplin siswa yaitu dengan melakukan pembiasaan. pembiasaan disini yaitu memberi pemahaman dan menerapkan perbuatan dan kegiatan baik yang telah guru kenalkan kepada siswa. Namun hal ini semua kegiatan tersebut tidak bisa dilakukan karena sekarang sedang berada dalam masa pandemi. Hal ini menyebabkan sejumlah sekolah terpaksa ditutup dan mengubah proses pembelajaran menggunakan sistem daring atau online. Penerapan karekter disiplin di era pandemi ini dapat diterapkan melalui tepat waktu atau tidaknya siswa untuk masuk kelas online. Selain itu, penguatan karkter disiplin siswa dapat dilakukan melalui proses pembiasaan yang bisa dilihat dari tepat waktu atau mereka mengumpulkan tugas. Namun pada bulan Desember 2020 terdapat beberapa sekolah sudah menerapkan model

pembelajaran

Hybrid

Learning. Pembelajaran Hybrid learning ini pembelajaran yang mana proses pembelajaran di bagi menjadi dua kelompok dalam satu kelas. Model pembelajaran hybrid learning ini proses pembelajaran irisan tatap muka dan online, seperti pembelajaran yang dilakukan didalam kelas dengan sebagian belajar di ruang kelas di sekolah dan sebagian di rumah secara online.

Berdasarkan permasalah diatas dapat diketahui tujuan dari penelitian ini secara umum adalah untuk mengetahui " seperti apa penguatan karekter disiplin belajar siswa melalui kegiatan pembiasaan pada pembelajaran Hybrid" sedangakan secar khusus adalah untuk mengetahui proses penguatan karakter disiplin terhadap siswa dalam kegiatan pembiasaan pada pembelajaran hybrid dan untuk mengetahui hasil proses penguatan karakter disiplin terhadap sisiwa dalam kegiatan pembisaan pada pembelajaran hybrid.

Manfaat penelitian diantaranya Secara teoritis, hasil penelitian ini diharapkan dapat menambah pengetahuan dan wawasan tentang kedisiplinan melalui kegiatan 
pembiasan pada pembelajaran Hybrid. Sedangkan secara praktis diantaranya, bagi siswa, hasil penelitian ini diharpkan agar siswa dapat meningkatkan karakter disiplin melalui kegiatan pembiasaan. Bagi Guru, hasil dari penelitian diharapkan agar guru dapat menumbuhkan dan menanamkan karakter disiplin kepada siswa melalui kegiatan pembiasaan pada pembelajaran Hybrid. Bagi Kepala Sekolah, hasil penelitian diharapkan kepala sekolah data memberi masukan untuk meningkatkan karakter disiplin siswa. Bagi peneliti, hasil penelitian diharapkan peneliti dapat mengetahui dan menambah pengetahuan mengenai kedisiplinan.

Penelitian dilakukan dengan mengambil tempat di SDN Anyar 2 tahun ajaran 2020-2021. Pemilihan lokasi ini didasarkan beberapa pertimbangan. Salah satunya sepengetahuan peneliti di SDN Anyar 2 belum pernah dilakukan penelitian yang sama. Data yang diperlukan oleh peneliti untuk menjawab masalah ini memungkinkan diperoleh di sekolah tersebut.kedisiplinan saat ini masih menjadi suatu permasalahan dimana sudah jarang sekali seseorang menerapkan sikap disiplin baik itu disiplin untuk diri sendiri untuk dilingkungan keluarga, sekolah, masyarakat. Untuk saat ini juga masih banyak siswa sekolah dasar yang kurang menerapkan sikap disiplin seperti tidak mengerjakan tugas sehingga pengumpulan tugas menjadi terlambat, selain itu juga saat pembelajaran dengan model hybrid learning dimana ada sebagain siswa yang sekolah di dalam kelas dan sekolah secara online dari rumah penerapan disiplin ketika mereka bagian masuk sekolah belajar tatap muka meraka terbiasa online menjadikan merka telat datang kesekolah dan untuk pengumpulan tigas yang sudah diberikan saat daring pun tidak semua dikumpulkan sebab mereka dirumah pun terkadang tidak langsung megerjakan tugas menjadikan tugas tertumpuk.

Data yang akan diperoleh dalam penelitian ini salah satunya untuk mengetahui proses penguatan karakter disiplin terhadap siswa dalam kegiatan pembiasaan pada pembelajaran hybrid. Peneliti memfokuskan permasalahan proses serta hasil penguatan disiplin belajar siswa melalui kegiatan pembiasaan pada pembelajaran hybrid. Adapun tujuan diadakannya penelitian ini 
supaya peneliti mengetahui bagaimana proses yang dilakukan untuk penguatan karakter disiplin

\section{B. Metode Penelitian}

Dalam penelitian ini menggunakan pendekatan kualitatif. Pendekatan kualitatif adalah pendekatan penelitian yang diarahkan untuk pencapaian tujuan memperoleh penjelasan secara mendalam atas penerapan sebuah teori (Rully, 2017: 29). Menurut Borg and Gall, metode kualitatif sering disebut sebagai metode baru, postpositivistic, discovery, interpretive dan kualitatif (Sugiyono, 2016: v). Sedangkan menurut Sugiyono (2014:9) metode kualitatif digunakan untuk meneliti pada kondisi subjek yang alamiah dimana peneliti adalah sebagai instrumen kunci, teknik pengumpulan data dilakukan secara triangulasi (gabungan), analisis data bersifat induktif, dan hasil penelitian kualitatif lebih menekankan pada makna dari pada generalisasi.

Dari beberapa pengertian diatas, dapat dipahami bahwa penelitian kualitatif adalah penelitian yang bertujuan untuk memahami fenomena pada subjek penelitian secara deskriptif, dalam konteks siswa melalui kegiatan pembiasaan pada pembelajaran hybrid.

alamiah, dengan mengumpulkn data secara truangulasi, analisis data bersifat induktif dan memanfaatkan baerbagai metode ilmiah yang ada dengan penelitian sebagai instrument kunci karena dalam penelitian ini peneliti yang merencanakan, melaksanakan, mengumpulkan data, menarik kesimpulan, dan menyusun laporan penelitian.

Data kualitatif ini sebagai deskripsi yang detail dan kaya, serta dapat menangkap variasi versi antar kejadian. Hal ini sejalan dengan pendapat patton, yang menyatakan bahwa pendekatan kualitatif dalam studi evaluasi ini dapat memberikan gambaran penting tentang sebuah program, analisis terhadap proses pelaksanaan program, perbedaan antara jenis partisipan dan partisipasi, perubahan program menjangkau partisipan serta analisa kelemahan dan kekuatan program.

Deskripsi yang detail tentang implementasi program. Dalam tulisan ini, pendekatan kualitatif yang digunakan penulis sangat bermanfaat untuk memperoleh informasi yang komperhensif mengenai detail proses 
penguatan karakter disiplin belajar terhadap siswa melalui kegiatan pembiasaan sebagai respon dari pelaksanaan kurikulum 2013 yang telah diberlakukan semenjak tahun 2013. Informasi kegiatan penguatan karakter disiplin belajar terhadap siswa melalui kegiatan pembiasaan dapat diperoleh untuk memperkaya data lapangan dalam analisis.

Analisis terhadap proses pelaksanaan program sebagai pendekatan kualitatif yang digunakan penulis untuk menggali informasi dari narasumber sangat membantu untuk menganalisis proses penguatan karakter disiplin siswa. Fokus utama dan analisis dalam tulisan ini adalah bagaimana peran guru dalam menanamkan karakter disiplin siswa.

\section{Hasil Penelitian dan Pembahasan}

Hasil penelitian dengan menggunakan teknik wawancara dan observasi. Peneliti melakukan observasi secara langsung untuk memperoleh hasill yang objektif dan akurat serta mengetahui secara langsung bagaimana proses yang dilakukan guru dalam penguatan karakter disiplin belajar terhadap siswa melalui kegiatan pembiasaan pada pembelajaran hybrid di SD Negeri Anyar 2. Metode yang digunkaan oleh peneliti yaitu metode deskriptif dan pada penelitian inii menggunakan jenis pendekatan kualitatif. Menurut Rully (2017:29) mengungkapkan bahwa pendekatan kualitatif adalah pendekatan penelitian yang diarahkan untuk pencapaian tujuan memperoleh penjelasan secara mendalam atas penerapan sebuah teori. Untuk tahap analisi, yang dilakuakn peneliti adalah dengan wawancara dan pengumpulan data dan juga analisis data. Guna mengtahui bagaimana penguatan karakter disiplin belajar terhadap siiswa mellaui kegiatan pembiasaan di SD Negeri Anyar 2. Berikut hasil penelitian dengan wawancara dan observasi meliputi ;

Untuk mengetahui proses penguatan karakter disiplin belajar terhadaap siswa dalam kegiatan pembiasaan pada pembelajaran hybrid

Pembiasaan merupakan proses pembentukan sikap melalui pembelajaran yang dilakukan secara berulang-ulang. Pembiasan dalam pendidikan sangat dibutuhkan siswa secara psikologis seperti halnya 
siswa mengikuti apa yang dilakukan dan dikatakan oleh guru saat proses pembelajaran. Pada penerapan pembelajaran hybrid ini membutuhkan kegiatan pembiasaan untuk penguatan karakter disiplin belajr siswa. untuk itu guru harus memiliki sikap yang baik sehingga guru akan menjadi sosok yang patut di gugu dan ditiru.

Dalam wawanacara yang sudah dilakuakn oleh peneliti kepada narasumber mengenai jenis, program kegiatan dan metode dalam kegiatan pembiasaan. menurut bu Inah selaku narasumber bahwa kegiatan pembiasaan yang ada disekolah diterapkan seperti leterasi dan juga program sabtu bersih.

Menurut Devi Fangestika (2018) sejalan dnegan tuntutan abad 21 kemendikbud terus berupaya mencari strategi untuk meningkatkan minat baca agar terciptanya budaya literasi pada peserta didik. Peratutran menteri pendidikan dan kebudayaan Nomor 23 tahun 2015 tentang penumbuhan budi pekerti. Amanat permendikbud ini dilaksanakan melalui pengembangan program gerakan literasi sekolah diwujudkan dengan wajib baca 15 menit sebelum pembelajran bagi siswa SD, SMP, dan SMA.

Karakter disiplin sangat penting dimiliki oleh manusia karena karakter disiplin dapat menggambarkan ciri khas yang dimiliki oleh seseorang. Disiplin bisa juga dikatakan sebagai proses dalam pendidikan seperti siswa dapat menerapkan karakter disiplin saat proses pembelajaran.

Dalam wawancara yang dilakuakn kepada narasumber mengenai sikap guru dalam penguatan karakter disiplin belajar menurut bu Inah, beliau sudah memberikan contoh dalam penguatan karakter disiplin yang terdapat dalam kegiatan pembiasaan pada pembelajaran hybrid. Seperti membantu menyapu saat siswa sedang melaksanakan tugas piket.

Menurut Rabiatul Adawiyah (2016) salah satu faktor penting yang sangat berperan di sekolah dalam mengembangkan nilai-nilai karakter adalah tenaga pendidik atau guru. Undang-undang Nomor 14 tahun 2005 tentang guru dan dosen, menyatakan bahwa seorang guru harus memiliki empat kompetensi, yaitu kompetensi professional, 
pedagogis, kepribadian dan sosial. Melalui empat kompetensi tersebut seorang guru diharapkan dapat mengembangkan nilai-nilai karakter bangsa baik nilai religius, kejujuran, disiplin, peduli lindungkumgan atau pun karkter lainnya.,

\section{Untuk mengetahui hasil proses penguatan karakter disiplin terhadap siswa dalam kegiatan pembiasaan pada pembelajaran hybrid}

Kesuksesan dapat diraih dengan menggunakan waktu yang dimiliki dengan baik. Sebab waktu merupakan hal berharga maka kita harus memaksimalkannya dengan cukup baik. Untuk menggunakan waktu dengan baik buna hanya perkara yang mudah kita perlu melatih agar terbiasa.

Dalam wawancara yang telah dilakukan kepada bu Inah mengenai sikap disiplin siswa menggunakan waktu dalam belajar dapat ditarik kesimpulan bahwa menurut bu Inah siswa sudah disiplin menggunakan waktu dalam belajar, seperti halnya siswa datang tepat waktu dan sudah berada diruang kelas sebelum pelajaran dimulai. Adapun untuk siswa yang bagian daring siswa tepat waktu dalam menggumpulkan tugas melalui whatAppGroup. Pada penelitian kepada siswa yang dilakukan peneliti, ternyata sesuai dengan apa yang dijelaskan oleh narasumber.

Menurut A.S.Moenir (2010:94) yang dikutip kembali oleh Adeng Hudaya (2018) mendefinisikan disiplin adalah " suatu bentuk dari ketaatan terhadap aturan baik, yang tertulis maupun tidak tertulisyang ditetapkan . indikator-indikator yang dapat digunakan untuk mengukur tingkat disiplin belajar siswa berdasarkan ketentuan disiplin waktu meliputi :

- Tepat waktu dalam belajar, mencakup datang dan

- Pulang sekolah tepat waktu, mulai dan selesai

- Be;lajar di sekolah tepat waktu, dan mulai dan selesai

- Belajar dirumah

- Tidak keluar/membolos saat pelajaran

- Menyelesaikan tugas sesuai waktu yang ditetapkan

$$
\text { Pada kegiatan proses }
$$

pembelajaran hal penting yang harus siswa lakukan ialah dengan membuat jadwal belajar dan sebagainya yang 
kelak akan mewujudkan keteraturan belajar siswa disaat proses pembelajaran berlangsung sehingga pembelajaran juga berjalan dengan efektif tujuan pembelajaran tersampaikan dengan baik.

Dalam wawancara yang sudah dilakukan kepada bu Inah tentang siswa menjadi lebih teratur dalam belajar. Dapat ditarik kesimpulan bahwa menurut $\mathrm{Bu}$ Inah terdapat siswa yang sudah teratur dalam belajar seperti mengerjakan dan mengumpulkan tugas tepat waktu tetapi masih ada yang belum teratur dalam belajar. Namun, saat peneliti melakukan observasi peneliti melihat bahwa masih terdapat siswa yang belum teratur dalam belajar.

Menurut pendapat Gie (1988) yang dikutip kembali oleh Yenni Anis dan tiga aspek untuk membentuk kebiasaan belajar yang efektif yakni : keteraturan, disiplin dan konsentrasi. Belajar secara teratur akan memperolehe hasil yang baik. Keteraturan meliputi kebiasaan mengikuti pelajaran secara teratur, menyimpan dan memlihara secara teratur alat perlengkapan belajar dan kebiasaan membaca buku-buku pelajaran.
Sikap disiplin adalah sebuah tingkah laku atau gerakan yang tampak dan ditampilkan dalam inetraksinya dengan lingkungan sosial. Sikap anak terhadap sekolah sangat besar pengaruhnya. Terutama saat proses pembelajaran. Sikap siswa saat proses pembelajaran memiliki pengaruh terhadap hasil belajar siswa.

Dalam wawancara yang dilakukan kepada bu Inah mengenai siswa menjadi lebih paham mengenai sikap dalam belajar. Dapat ditarik kesimpulan bahwa menurut bu Inah terdapat siswa yang mudah memahami akan sikapnya saat belajar. namun, saat peneliti melakukan observasi peneliti melihat bahwa ada beberapa sisw amasih belum memhami sikapsnya sata belajar seperti kurang jujur dalam mengerjakan tugas yang diberikan oleh bu Inah.

Menurut Slameto (2003) yang dikutip kembali oleh Maman Achidat (20018) mengemukakan sikap belajar penting karena didasarkan atas peranan guru sebagai pengajar dalam proses belajar mengajar. Menurut Maman Acdiyat (2018) sikap belajar ikut menentukan intensitas 
kegiatan belajar yang positif akan menimbulkan intensitas kegiatan yang lebih tinggi di bandingkan dengan sikap belajar yang mudah.

Sikap disiplin sangat penting dalam proses pendidikan, karena itu setiap sekolah memiliki sebuah peraturan yang harus dipatuhi baik itu oleh guru maupun siswa. menaati peraturan merupakan kewajiban yang harus dilaksanakan pada waktu dan tempat tertentu.

Dalam wawancara yang sudah dilakukan peneliti kepada narasumber mengenai siswa dalam menaati peraturan disekolah dapat ditarik kesimpulan bahwa menurut bu Inah siswa sudah mampu menaati peraturan yang ada di sekolah. Namun siswa peneliti kepada siswa yang dilakukan peneliti, ternyata masih ada bebrapa siswa yang melanggar peraturan yang ada.

Menurut arikunto (1990:137) yang dikutip oleh Bella Puspita Sari (2017) mengemukakan bahwa macam-macam disiplin belajar ditunjukan oleh perilaku yaitu, menaati tata tertib sekolah, perilaku kedisiplinan didalam kelas, disiplin dalam menempati jadwal belajar dan velajar secara teratur.

\section{Kesimpulan}

Guru memanfaatkan program pembiasan ini sebagai salah satu program yang mendukung penguatan terhadap karakter siswa. Adapun untuk kegiatan pembiasaan sudah cukup maksimal untuk penguatan karakter disiplin belajar siswa. Penguatan disiplin perlu dilakukan karena masih banyak dijumpai perilaku yang menyimpang dari norma kedisiplinan. Penguatan disiplin dilaksanakan dengan melakukan beberapa aspek seperti memberi keteladanan dan penegakan peraturan. Terlihat saat proses yang dilakukan dalam penguatan karakter disiplin melalui kegiatan pembiasaan terjadinya peningkatan karakter disiplin pada siswa. Peningkatan yang terjadi pada siswa dapat diraih kesimpulan bahwa proses yang sudah dilaksanakan oleh sekolah dengan hasil yang cukup baik dalam penguatan karakter disiplin. Terbukti dengan kegiatan yang membuat siswa menjadi lebih disiplin. 


\section{DAFTAR PUSTAKA}

Anis, Yenni. (2018). Hubungan antara kebiasaan efektif dengan prestasi belajar siswa. Jurnal penelitian dan kajian sosial keagamaan. Vol. 15 No. 2 : 103

Hudaya, Adeng. (2018). Pengaruh Gadget terhadap Sikap Disiplin dan Minat Belajar Peserta Didik. Jurnal Of Education. Vol. 4 No. 2

Mulyawati, Yuli., dkk (2019). Pengaruh Disiplin Belajar Terhadap Hasil Belajar IImu Pengetahuan Sosial. Jurnal Ilmiah Pendidikan, 3(1).

Purandina, I Putu Yoga. (2020).

Pendidikan Karakter di

Lingkungan Keluarga Selama Pembelajaran Jarak Jauh pada Masa Pandemi COVID-19. Jurnal ilmu pendidikan, 2(3), 270-290

Sugiyono. (2016). Metode Penelitian Kuantitatif, Kualitatif, dan R\&D. Bandung : Alfabeta

Manab, Abdul. (2015). Penelitian Pendidikan Pendeketan Kualitatif, Depok Sleman Yogyakarta : Kalimedia 